\title{
ALLOCATION OF WORKING TIME OF RICE FARMER'S HOUSEHOLD GENDER PERSPECTIVE IN TANAH MIRING DISTRICT MERAUKE REGENCY
}

\author{
Suroto \\ Masters Program in Economics \& Development Studies, Diponegoro University \\ E-mail: surotounmus@gmail.com
}

Received: March 2019; Accepted: May 2019; Available online: July 2019

\begin{abstract}
This research aims to analyze work time allocation and the factors that influence the allocation of working time on the farming of rice made by man (husband) and women (wife) and the role of gender occurring within the household. The analytical approach used the average tabulation, multiple linear regression, and Harvard Model gender analysis. This research used cross section data with a sample of 100 husbands and 100 wives of households of rice farmers. The results showed that the amount of working time allocation for husband is greater than the allocation of wife working time. Work time allocation the husband influenced by land area and the amount of production.Wife's work time allocation are affected by land area, education level, and the family members number. Gender analysis results show the husband more productive activities and on the role of the wife on reproductive activities. Access and control in the household more done by husbands. The factors that provide a positive impact, namely the region demographic structure, institution/economic factors, the training performed by government institutions, and the attitude of the society that received intervention from outside. The factors which provide negative effects namely the norms of the community, and the local customary law.

Keywords: Allocation of working time, household of the farmer, gender analysis of Harvard Model

Abstrak

Penelitian ini bertujuan untuk menganalisis: alokasi waktu kerja, faktor-faktor yang mempengaruhi alokasi waktu kerja laki-laki (suami) dan perempuan (istri) pada pertanian padi, dan peran gender yang terjadi dalam rumah tangga. Pendekatan analisis menggunakan model analisis tabulasi rata-rata, analisis regresi linier berganda, dan analisis gender model Harvard. Penelitian ini menggunakan data cross section dengan sampel sebanyak 100 lakilaki (suami) dan 100 perempuan (istri) rumah tangga petani padi. Hasil penelitian menunjukkan pada pertanian padi jumlah alokasi waktu kerja laki-laki (suami) lebih besar dari jumlah alokasi waktu kerja perempuan (istri). Alokasi waktu kerja laki-laki (suami) pada pertanian padi dipengaruhi oleh luas tanah dan jumlah produksi. Alokasi waktu kerja perempuan (istri) pada pertanian padi dipengaruhi oleh luas lahan, tingkat pendidikan, dan jumlah anggota keluarga. Hasil analisis gender menunjukkan laki-laki (suami) lebih banyak melakukan peran produktif dan perempuan (istri) lebih banyak melakukan peran reproduktif. Akses dan kontrol dalam rumah tangga lebih banyak dilakukan oleh laki-laki (suami). Faktor-faktor yang memberikan dampak positif, yaitu struktur demografi, faktor lembaga ekonomi, pelatihan dilakukan oleh lembaga-lembaga pemerintah, dan sikap masyarakat yang menerima intervensi dari luar. Faktor-faktor yang memberikan dampak negatif yaitu normanorma masyarakat, dan hukum adat setempat.
\end{abstract}

Kata kunci : alokasi waktu kerja, rumah tangga petani, analisis gender Model Harvard

How to Cite: Suroto. (2019). Allocation of Working Time of Rice Farmer's Household Gender Perspective in Tanah Miring District Merauke Regency. Media Ekonomi dan Manajemen, 34(2), 137-152. 


\section{INTRODUCTION}

Rice plants in Papua Province are recorded as food crops with an average annual growth of 13.04 percent (Dewan Ketahanan Pangan Papua, Badan Ketahanan Pangan dan Koordinasi Penyuluhan Papua, \& World Food Programe, 2015). Rice is the staple food crops as a very important globally (Adenuga et al., 2013). Merauke Regency is the largest rice producing area with an annual average production of over 80 percent of the total paddy production in Papua Province (Badan Pusat Statistik Kabupaten Merauke, 2016). The Government of Merauke Regency since 1963-2001 has brought in transmigrants from Java who reached as many as 25,036 families or 96,637 people and opened up an area of agricultural land of 50,072 hectares. The transmigrant area has now become a food barn (Soetanto, 2008). One of the transmigrant areas is the Tanah Miring District, which is the largest rice producer in Merauke Regency.

Rice farming is the source of livelihood for almost all households in the Tanah Miring District of Merauke Regency (Badan Pusat Statistik Kabupaten Merauke, 2016). Increasing in rice production in Tanah Miring District is one of them by increasing human resources through the utilization of the potential of rice farmers, such as the traditions of local communities became part of a culture passed from generation to generation through the farm family. The culture of rice farming was a cultural heritage has become the key to the identity of the Indonesian people for a long time.

The time ( 24 hours) owned by the household is an important fundamental component of the life strategy used to carry out various types of activities to achieve individual goals and collectively in the household. In rice farming other than land, seeds and equipment, there is an allocation of time devoted by farmers determines the amount of rice production produced. The allocation of working time in the rice agriculture sector is generally performed by men (husbands) while women (wives) who work in rice farming are only helpful.

Allocations of working time in farmer households are grouped into two types of activities, namely productive activities and reproductive activities. Productive activity is an activity in a household has an economic exchange rate both directly and in the future. Reproductive activity is an activity in the household does not bring economic value to the family but the benefits from these activities can be enjoyed together in the family. In general, in the farmer households productive activities are carried out more by man and women doing more reproductive activities.

The development of farmer households certainly begins from the level of quality of human resources owned by households, both men (husbands) and women (wives) who are the main actors who play a role in the development of farmer households. Achieving optimal development of farmer households requires equality of involvement between men (husbands) and women (wives) in agricultural work, work outside agriculture, and household work. Viewing the role of men (husbands) and women (wives) in the development of farmer households requires gender equality which is principled on humanism, justice and places men (husbands) and women (wives) as central in the construction of rice farmer household.

\section{Purpose of the Research}

The purpose of research on gender based working time allocation in domestic households includes: 1) analyzing the allocation of time and type of work of men (husbands) and women (wives) on rice farming in the Tanah Miring District of Merauke Regency, 2) analyzing what factors influence the allocation of working time of men (husbands) and women (wives) on rice farming in the Tanah Miring District of Merauke Regency, and 3) analyzing gender roles in rice farming households in Tanah Miring District of Merauke Regency. 


\section{LITERATURE REVIEW}

\section{Theory of Working Time Allocation}

The farmer household is a unique combination of men (husbands) and women (wives), adults and children who all provide management in the household, knowledge, labor, capital, and land for farming that consumes at least a portion of the farm produced. Thus, farmer households are at the center of resource allocation, production and consumption (Reijntjes, 1999).

The strategy of households' reflection for prosperous living is indicated by the working contribution of family members in earning a living. Working contribution is a reflection of the production system in the household. Household members in each of their activities are looking for use value which ultimately results in household welfare. Each member of the household or household as a whole should take into account the problems or limiting factors and economic opportunities in meeting needs (Mangkuprawira, 1985).

According to Ehrenberg \& Smith (2003) someone in allocating time is faced with two choices, namely working or not working to enjoy his/her leisure time. Working means producing wages which will further increase income. Whereas according to Nicholson (1999) each individual has two options in using his/her time, namely: working with a wage of $W$ per hour and free time (leisure time) is not used to work or conduct activities that are not economical because they do not get rewards or wages.

\section{Theory of Gender}

According to Khuza'i (2013) gender is a social "gender" in the form of masculine or feminine attributes which is a sociocultural construction. Masculine attributes do not have to be attached to male sex and feminine character is also not necessary for women, because these attributes are not natural in nature, but are formed sociohistorically which are unfixed and can be learned, so they can be exchanged across sex.
The concept of gender refers to a trait inherent in both men and women constructed both socially and culturally. This situation will change according to time, location, and different socio-cultural environments. For example, women are known to be gentle, beautiful, emotional or motherly. While men are considered strong, rational, manly, and mighty. The characteristics of these properties are properties can be exchanged. This means that there are men who are emotional, gentle, motherly, while there are also women who are strong, rational, and mighty. Changes in the characteristics of those traits can occur from time to time and from place to place. Changes can also occur from different classes to community classes. In certain ethnic group lower-class women in the countryside are stronger than men. All things can be exchanged between the nature of women and men can change from time to time and differ from place to place and differ from one class to another class is what is known as the concept of gender (Taridala, et al, 2010).

\section{RESEARCH METHODS}

The location of the study taken purposively of one district as a population has the most productive level of rice farming productivity in Merauke Regency. Determination of the number of samples for each village chosen using the quota sampling method. This method, researcher determines the quota (number) of a sample of 100 rice farmer households from a population of 1,835 rice farmer households (Istijanto, 2005). The selection from each village is taken for data using convenience sampling. Through this method, researcher is take data on rice farmers based on a sample has been determined by the number of each village. Researcher looks for paddy farmers who are easily found in the workplace (rice fields) or at home to retrieve data by interview using a questionnaire (Istijanto, 2005). 


\section{Data Analysis}

Answering the purpose of this study, the method of data analysis is used as follows:

1. Knowing the time allocation and type of household work for male farmers (husband) and women (wives) in rice farming, the following formula is used (Saleh \& Yunilas, 2004; Lindawati, 2015):

$$
A T_{l_{p},},=A_{l}+A_{b}+A_{p}+A_{y}+A_{f}+A_{h}+A_{n}
$$

Where:

$$
A T_{l, p}=\text { Total allocation of working time }
$$
for men (husbands) or women (wives) on rice farming (planting hours / seasons);

$A_{l} \quad=$ Allocation of working time for men (husbands) or women (wives) in the work of cleaning rice fields (hours / planting season);

$A_{b}=$ Allocation of working time for men (husbands) or women (wives) on rice farming nursery work (hours/planting season);

$A_{p}=$ Allocation of working time for men (husbands) or women (wives) in planting rice farming work (hours / planting seasons);

$A_{y}=$ Allocation of working time for men (husbands) or women (wives) in the working of weeding rice farming (hours/planting season);

$A_{f} \quad=$ Allocation of working time for men (husbands) or women (wives) in the work of fertilizing rice farming (hours / planting seasons);

$A_{h}=$ Allocation of working time for men (husbands) or women (wives) in eradicating work of rice farming (hours / planting season); and

$A_{n}=$ Allocation of working time for men (husbands) or women (wives) in paddy farming work is harvested until post-harvest (grain is ready to be milled or sell) (hours/planting season).

2. Observing the factors influence the time allocation of men (husbands) and women (wives) on rice farming used regression analysis with the Ordinary Least Square (OLS) method (Gujarati \& Porter, 2009). The mathematical models of multiple linear regression equations are as follows:

1. Multiple linear regression analysis model allocation of male working time (husband) on rice farming.

$$
\begin{aligned}
H_{l i}= & \lambda+\lambda_{1} U_{l i}+\lambda_{2} P_{l i}+\lambda_{3} J_{k i}+ \\
& \lambda_{4} L_{i}+\lambda_{5} \text { prod }_{i}+\lambda_{6} Y_{u l i}+e_{i}
\end{aligned}
$$

Where:

$H_{l} \quad=$ allocation of male working time (husband) on rice farming (hours per season);

$i=$ observation;

$\lambda=$ coefficient of regression;

$U_{l} \quad=$ age of man (husband);

$P_{l} \quad=$ education of man (husband);

$I_{k}=$ number of the family

member;

$L \quad=$ large of paddy agriculture area;

prod $=$ rice production in one planting season;

$Y_{u l}=$ income of family business other than rice farming in one planting season; and

$e \quad=$ error disturber.

2. The multiple linear regression analysis model allocation of the working time of women (wives) to rice farming

$$
\begin{aligned}
H_{p i}= & \lambda+\lambda_{1} U_{p i}+\lambda_{2} P_{p i}+\lambda_{3} J_{k i}+ \\
& \lambda_{4} L_{i}+\lambda_{5} \text { prod }_{i}+\lambda_{6} Y_{w i i}+e_{i}
\end{aligned}
$$

where:

$H_{p} \quad=$ allocation of female working time (wife) on rice farming (hours per season);

$i=$ observation;

$\lambda=$ coefficient of regression; 


$$
\begin{aligned}
U_{p}= & \text { age of woman (wife); } \\
P_{p}= & \text { education of woman (wife); } \\
l_{k}= & \text { number of the family member; } \\
L= & \text { large of paddy agriculture } \\
& \text { area; } \\
\text { prod }= & \text { rice production in one } \\
& \text { planting season; } \\
Y_{u l}= & \text { income of family business } \\
& \text { other than rice farming in one } \\
& \text { planting season; and } \\
e= & \text { error disturber. }
\end{aligned}
$$

3. Analysis used to analyze gender roles using the Harvard Model gender analysis

The gender analysis of the Harvard Model includes three roles or triple roles namely; (1) analysis of the role profile of activities with productive activities and reproductive activities, (2) analysis of the access role and control of resources and benefits, and (3) analysis factors are influencing the activities of one profile of activities and activities of two access and control (Puspitawati, 2012).

\section{RESULT AND DISCUSSION}

\section{Allocation of working time and type of work on rice farming}

Allocation of working time based on the type of household work of rice farmers in Table 1 shows the average number of male

\begin{tabular}{|c|c|}
\hline Type of working & $\begin{array}{l}\text { Husband Wife } \\
\text { (Hours) (Hours) }\end{array}$ \\
\hline 1 Land clearing $\left(A_{l}\right)$ & $85,66 \quad 55,50$ \\
\hline 2 Nursery $\left(A_{b}\right)$ & 3,18 \\
\hline 3 Planting $\left(A_{p}\right)$ & 20,60 \\
\hline 4 Weeding $\left(A_{y}\right)$ & 13,47 \\
\hline 5 Fertilization $\left(A_{f}\right)$ & 21,47 \\
\hline 6 Eradication of pests $\left(A_{h}\right)$ & 47,46 \\
\hline 7 Harvest-Post harvest $\left(A_{n}\right)$ & 112,90 \\
\hline Total $\left(A T_{l, p}\right)$ & $305,64 \quad 173,32$ \\
\hline
\end{tabular}
work time allocations (husband) in paddy agriculture amounting to 305.64 hours, greater than the average number of female working time allocations (wives) amounting to 173.32 hours. The allocation of male working time (husband) is greater than the amount of working time allocated for women (wives) in all types of rice farming work.
Table 1. Amount of Average Allocation of Household Working Time

Source: Processed Primary Data, 2018

The amount of working time allocation for men (husbands) on rice farming shows that the potential of men (husbands) is greater than women (wives) and the labor they donated is greater, it can be said that men (husbands) are leader in farming and leader in the family. As the head of the household, it is more responsible for meeting the needs of household members.

The small amount of working time allocation for women (wives) in rice farming is caused, the work of rice farming is not a compulsory work that must be carried out by women (wives). The participation of women (wives) in rice farming is a form of assistance to increase family income. From the results of gender analysis women (wives) do more reproductive work in the household.

Detect Classical Assumptions for Allocation of Male Working Time (Husband)

\section{Detection of Residual Normality}

Detection of Residual use Normality test Jarque-Bera by using the values of Skewness and Kurtosis values (Kabasarang, Setiawan, \& Susanto, 2013). 
Table 2. Value of Skewness and Kurtosis

\begin{tabular}{ccc}
\hline N Statistic & Skewness & Kurtosis \\
\hline \hline 87 & $-0,219$ & 0,319
\end{tabular}

Source : Processed Primary Data, 2018

The Skewness value and Kurtosis value in Table 2 are included in the equation model to be as follows:

$J B=87\left(\frac{-0,219^{2}}{6}+\frac{0,319^{2}}{24}\right)=0,33$

Jaque-Bera value is 0,33 with a significance level of 0,05 , then the Chi Square value is equal to $(\mathrm{db}=5,99, \alpha=0,05)$. The JarqueBera value of 0,33 shows that it is smaller than the Chi Square value of 5,99, then the residual distribution of the regression equation is normally distributed.

\section{Multicollinearity Detection}

The problem of multicollinearity is seen through the results of the data processing output, if the Variance Inflation Factor (VIF) is 0,10 or 10 percent then there is no problem with multicollinearity (Ghozali, 2016).

Table 3. Variance Inflation Factor (VIF) Value

\begin{tabular}{clc}
\hline No & Variable & VIF \\
\hline 1 & Age of husband & 1,114 \\
\hline 2 & Education of husband & 1,090 \\
\hline 3 & Number of the family member & 1,061 \\
4 & Large of area & 4,787 \\
5 & Production & 4,780 \\
6 & $\begin{array}{l}\text { Operating income other than } \\
\text { rice farming }\end{array}$ & 1,044 \\
\hline \hline
\end{tabular}

Source : Processed Primary Data, 2018

All independent variables in Table 3 show the value of Variance Inflation Factor (VIF) $<0,10$ or 10 percent, meaning that there is no linear relationship between the independent variables in the research model.

\section{Detection Park}

Detect Park by looking at the beta parameter coefficient of the regression equation. If the results are statistically significant, this shows that in the empirical model estimates there are heteroscedasticity, and vice versa if the beta parameters are not statistically significant, then the assumption of homoskedasticity in the empirical model is accepted (Ghozali, 2016).

Table 4. Detection Park

\begin{tabular}{cll}
\hline No & \multicolumn{1}{c}{ Variable } & Sig \\
\hline 1 & Age of husband & 0,191 \\
\hline 2 & Education of husband & 0,314 \\
\hline 3 & Number of the family member & 0,322 \\
4 & Large of area & 0,592 \\
\hline 5 & Production & 0,062 \\
\hline 6 & $\begin{array}{l}\text { Operating income other than } \\
\text { rice farming }\end{array}$ & 0,905 \\
\hline \hline
\end{tabular}

Source : Processed Primary Data, 2018

All independent variables in Table 4 show no significant results at 5 percent or $>$ 0,05 , then the assumption of homoskedasticity in the empirical model is accepted or in the empirical model there is no heteroscedasticity.

\section{Regression Analysis Allocation of Male Working Time (Husband)}

The analysis of multiple linear regression in Table 5 shows a constant value with a coefficient of 139.860 with a statistical $\mathrm{t}$ value of 2.649 significant at $\alpha=$ 0.050 . At the coefficient of determination $\left(\mathrm{R}^{2}\right)$ of 0.734 , it means that 73.4 percent variation in changes in the dependent variable allocation of male working time (husband) on rice farming can be explained by six independent variables, while for 0.266 or 26.6 percent variations in changes in the dependent variable cannot be explained by empirical models. 
Table 5. Regression Allocation of Male Working Time (Husband)

\begin{tabular}{clr}
\hline No & \multicolumn{1}{c}{ Variable } & Coefficients \\
\hline 1 & Age of husband (X1) & $\begin{array}{r}-0,027 \\
(-0,436)\end{array}$ \\
\hline 2 & $\begin{array}{l}\text { Education of husband } \\
(\mathrm{X} 2)\end{array}$ & $\begin{array}{r}-0,058 \\
(-0,965)\end{array}$ \\
3 & Number of the family & $-0,037$ \\
& member (X3) & $(-0,626)$ \\
4 & Large of area (X4) & 0,504 \\
& & $(3,991)^{* * *}$ \\
5 & Production (X5) & 0,375 \\
& & $(2,976)^{* * *}$ \\
\hline 6 & Operating income other & $-0,006$ \\
& than rice farming (X6) & $(-0,095)$ \\
\hline Constanta & 139,860 \\
& & $(2,649)^{* * *}$ \\
\hline $\mathrm{R}^{2}$ & & 0,734 \\
\hline $\mathrm{t}$ table & 1,661 \\
\hline \hline
\end{tabular}

Source: Processed Primary Data, 2018

Note : * significant at $10 \%, * *$ significant at $5 \%$, $* * *$ significant at $1 \%$

Result of research showed that there were two variables had a significant positive effect on the allocation of male working time (husband) on rice farming, namely: (1) land area variable (X4) showed a positive coefficient value of 0.504 with a $t$ value of 3.991 greater than t table 1.661 is significant at $\alpha=0.050$. Statistically the regression analysis coefficient has a meaning, there is a significant relationship between the ownership of the area of paddy agricultural land to the number of male working time allocation (husband) on rice farming. This result is interpreted, if the ownership of paddy agricultural land increases by one percent, it will increase the amount of male working time allocation (husband) in paddy farming by 0.504 or 50.4 percent. (2) the production variable (X5) shows a positive coefficient value of 0.375 with a statistical $t$ value of 2.976 greater than the value of $t$ table 1.661 significant at $\alpha=0.050$. Statistically the regression analysis coefficient has a meaning, there is a significant relationship between rice production produced on the number of male working time allocation (husband) on rice farming. This result is interpreted, if there is an increase in the amount of rice production by one percent, then it has been influenced by increasing the number of male working time allocation (husband) of 0.375 or 37.5 percent in rice farming.

On the husband's age variable (X1), husband's education (X2), number of family members (X3), and business income other than rice farming (X6) did not have a significant effect on the allocation of male working time (husband) on rice farming. The causes include, among others, the low level of education of farmers and the use of technology in agriculture ranging from land acquisition to harvesting. While the amount of household income other than rice farming does not have a significant influence on the allocation of male working time (husband) on rice farming, because rice farming is a staple of livelihoods and jobs other than rice farming are carried out at leisure time after completing rice farming work or when waiting for the rice planted available to be harvested.

\section{Detection of Classical Assumptions for Allocation of Working Time for Women (Wives)}

\section{Detection of Residual Normality}

Detecting Residual Normality using the Jarque-Bera test using Skewness and Kurtosis values (Kabasarang et al., 2013).

Table 6. Skewness and Kurtosis values

\begin{tabular}{ccc}
\hline N Statistic & Skewness & Kurtosis \\
\hline \hline 82 & 0,130 & 1,246 \\
\hline
\end{tabular}

Source : Processed Primary Data, 2018

The Skewness value and Kurtosis value in Table 6 are included in the equation model to be as follows:

$J B=82\left(\frac{0,130^{2}}{6}+\frac{1,246^{2}}{24}\right)=5,54$

Jaque-Bera value is 5,54 with a significance level of 0,05 , then the Chi Square value is equal to $(\mathrm{db}=5,99, \alpha=$ $0,05)$. The Jarque-Bera value of 5,54 shows that it is smaller than the Chi Square value of 5,99 , then shows the distribution of residual 
regression equations that are normally distributed.

\section{Multicollinearity Detection}

Multicollinearity problems are seen through the results of data processing output, if the Variance Inflation Factor (VIF) is 0,10 or 10 percent then there is no problem with multicollinearity (Ghozali, 2016).

Table 7. Variance Inflation Factor (VIF) Value

\begin{tabular}{clc}
\hline No & \multicolumn{1}{c}{ Variable } & VIF \\
\hline 1 & Age of wife & 1,529 \\
\hline 2 & Education of wife & 1,505 \\
\hline 3 & $\begin{array}{l}\text { Number of the family } \\
\text { members }\end{array}$ & 1,058 \\
4 & Large of area & 5,250 \\
\hline 5 & Production & 5,208 \\
\hline 6 & $\begin{array}{l}\text { Operating income other than } \\
\text { rice farming }\end{array}$ & 1,039 \\
\hline \hline
\end{tabular}

Source : Processed of Primary Data, 2018

All independent variables in Table 7 show the value of Variance Inflation Factor (VIF) $<0,10$ or 10 percent, meaning that there is no linear relationship between the independent variables in the research model.

\section{Detection Park}

Detect Park by looking at the beta parameter coefficient of the regression equation. If the results are statistically significant, this shows that in the empirical model estimated there is heteroscedasticity, and vice versa if the beta parameter is not statistically significant, then the assumption of homoskedasticity in the empirical model is accepted (Ghozali, 2016).

Table 8. Detection Park

\begin{tabular}{clc}
\hline No & \multicolumn{1}{c}{ Variable } & Sig \\
\hline 1 & Age of wife & 0,514 \\
\hline 2 & Education of wife & 0,494 \\
\hline 3 & Number of the family members & 0,503 \\
\hline 4 & Large of area & 0,146 \\
\hline 5 & Production & 0,068 \\
\hline 6 & $\begin{array}{l}\text { Operating income other than } \\
\text { rice farming }\end{array}$ & 0,974 \\
\hline Source & : Processed of Primary Data, 2018 & \\
\hline
\end{tabular}

All independent variables in Table 8 show no significant results at 5 percent or $>$ 0,05 , then the assumption of homoskedasticity in the empirical model is accepted or in the empirical model there is no heteroscedasticity.

\section{Regression Analysis Allocation of Woman Working Time (Wife)}

The multiple linear regression analysis in Table 9 shows the constant value with a coefficient of 122.450 with a statistical value of $\mathrm{t} 2.020$ significant at $\alpha=$ 0.050 . At the coefficient of determination $\left(\mathrm{R}^{2}\right)$ of 0.651 , it means that 65.1 percent of the variation in changes in the dependent variable allocation of working time for women (wives) in rice farming can be explained by six independent variables, while 0.349 or 34.9 percent changes variation in the dependent variable cannot be explained by empirical models.

Table 9. Regression of Allocation of Woman Working Time (Wife)

\begin{tabular}{|c|c|c|}
\hline No & Variable & Coefficients \\
\hline \multirow{2}{*}{1} & Age of wife (X1) & $-0,023$ \\
\hline & & $(-0,270)$ \\
\hline \multirow[t]{2}{*}{2} & Education of wife (X2) & $-0,206$ \\
\hline & & $(-2,457)^{* *}$ \\
\hline \multirow[t]{2}{*}{3} & Number of the family & $-0,154$ \\
\hline & members (X3) & $(-2,193)^{* *}$ \\
\hline \multirow[t]{2}{*}{4} & Large of area (X4) & 0,736 \\
\hline & & $(4,703)^{* * *}$ \\
\hline \multirow[t]{2}{*}{5} & Production (X5) & 0,082 \\
\hline & & $(0,525)$ \\
\hline \multirow[t]{2}{*}{6} & Operating income other & 0,007 \\
\hline & than rice farming (X6) & 0,100 \\
\hline \multirow{2}{*}{\multicolumn{2}{|c|}{ Constanta }} & 122,450 \\
\hline & & $(2,020) * *$ \\
\hline \multicolumn{2}{|c|}{$\mathrm{R}^{2}$} & 0,651 \\
\hline \multicolumn{2}{|c|}{$\mathrm{t}$ table } & 1,661 \\
\hline
\end{tabular}


Results of the research showed that there were two variables had a negative influence and one variable had a significant positive influence on the allocation of women's working time (wives) on rice farming, namely: (1) wife's education variable (X2) showed a negative coefficient of -0.206 with a t-statistic value -2.457 is greater than the value of $\mathrm{t}$ table -1.681 significant at $\alpha=0.050$. Statistically the regression analysis coefficient has a negative significant correlation between the influence of the education level of women (wives) and the amount of time allocated for working women (wives) on rice farming. This result is interpreted, if the level of education owned by women (wives) increases for one year, then women (wives) will reduce the amount of working time allocated to rice farming by 0.206 or 20.6 percent. (2) the variable number of family members (X3) shows a negative coefficient value of -0.154 with a statistical t-value of -2.193 greater than the value of $\mathrm{t}$ table -1.661 significant at $\alpha=$ 0.050. Statistically this regression coefficient has a significant negative relationship between the number of family members and the amount of time allocated for working women (wives) on rice farming. This result is interpreted, if the number of family members in the household increases by one person, women (wives) will reduce the amount of working time allocated to rice farming by 0.154 or 15.4 percent. (3) Land area variable $(\mathrm{X} 4)$ shows positive coefficient value of 0.736 , with $t$ value of 4.703 statistic greater than $t$ table value of 1.661 significant at $\alpha=0.050$. Statistically the regression analysis coefficient has a significant positive relationship between the area of agricultural land with the amount of time allocated for working women (wives) on rice farming. These results are interpreted, if the farmer's household increases the ownership of rice farming area by one percent, it will affect the increase in the number of women's working time (wives) in paddy agriculture by 0.736 or 73.6 percent.

On the wife's age variable (X1), production (X5), and business income other than rice farming (X6) do not have a significant effect on the allocation of women's working time (wives) on rice farming. One reason is that women (wives) are more obliged to do household reproductive work, rice farming work is carried out after completing household reproductive work. In addition, the use of agricultural technology causes women (wives) can only help with certain types of rice farming work. Influence at the level of education which results are negative is suspected, increasing the level of education of women (wives) will have the opportunity to work in addition to rice farming work to help increase family income. On the number of family members having a negative effect, it is suspected that the increasing number of family members will increase household reproductive work which makes women (wives) allocate more time to household reproductive work and reduce the amount of working time allocated to rice farming.

\section{Gender Analysis of the Farmer's Household of the Harvard Model}

\section{Activity Profile}

The activity profile consists of two activities in the farmer's household, namely productive activities and reproductive activities.

\section{Productive Activities}

Productive activities are household activities produce goods or services having economic value, in the form of wages for work or income used for family needs and those who carry out these activities. The results of economic values from productive activities can be produced or accepted at the present or future time. 
Table 10. Profile of Productive Activities.

\begin{tabular}{clcc}
\hline No & Type of working & $\begin{array}{c}\text { Husband } \\
(\%)\end{array}$ & $\begin{array}{c}\text { Wife } \\
(\%)\end{array}$ \\
\hline 1 & Land clearing & 100 & 72 \\
\hline 2 & Nursery & 47 & 37 \\
\hline 3 & Planting & 99 & 89 \\
\hline 4 & Weeding & 98 & 20 \\
\hline 5 & Fertilization & 100 & 52 \\
\hline 6 & Eradication of pests & 100 & 11 \\
\hline 7 & Harvest-Post harvest & 100 & 100 \\
\hline 8 & Livestock & 46 & 85 \\
\hline 9 & Fishery & 3 & 3 \\
\hline 10 & Trading & 10 & 13 \\
\hline 11 & Vegetable and fruit & 35 & 34 \\
$\quad$ gardening & & \\
\hline 12 & Others & 56 & 52 \\
\hline & Average & 78 & 56 \\
\hline \hline
\end{tabular}

Source: Processed of Primary Data, 2018.

Table 10 shows the average male (husband) as much as 78 percent participating in allocating work time to productive activities and women (wives) as much as 56 percent. This number shows that men (husbands) more allocate productive work than women (wives). The dominance of the allocation of working time for men (husbands) in almost all productive activities. This result shows that the male (husband) as the head of the household is more responsible for fulfilling household needs.

\section{Reproductive Activities}

Reproductive activities are of no economic value or not valued by money if carried out in their own household. The benefits of reproductive activities are enjoyed by the family together.
Table 11. Reproductive Activity Profiles.

\begin{tabular}{llrr}
\hline No & Type of working & $\begin{array}{c}\text { Husband } \\
(\%)\end{array}$ & $\begin{array}{r}\text { Wife } \\
(\%)\end{array}$ \\
\hline 1 & Taking care of children & 20 & 100 \\
\hline 2 & Cooking & 8 & 100 \\
\hline 3 & Cleaning up the house & 17 & 100 \\
\hline 4 & Taking water & 43 & 74 \\
\hline 5 & Taking firewood & 64 & 53 \\
\hline 6 & Repairing the house & 100 & 0 \\
\hline 7 & $\begin{array}{l}\text { Taking care of illness } \\
\text { children }\end{array}$ & 95 & 100 \\
\hline 8 & $\begin{array}{l}\text { Supervise children in } \\
\text { studying }\end{array}$ & 90 & 38 \\
\hline 9 & Go to the market & 26 & 99 \\
\hline \multicolumn{2}{c}{ Average } & 45 & 65 \\
\hline \hline
\end{tabular}

Source: Processed of Primary Data, 2018.

Table 11 shows an average of 45 percent of men (husbands) participated in allocating working time to reproductive activities and women (wives) by 65 percent. This number indicates that men (husbands) make fewer reproductive work allocations than women (wives). The dominance of women (wives) in reproductive work shows that women (wives) as housewives who have a production (giving birth) function are more obliged to do reproductive work (Rosada \& Nurliani, 2016).

\section{Access and Control}

Access and control are two different concepts, but in the fact that these two concepts are inseparable and interrelated. Access is an opportunity or chance can be achieved by men (husbands) and women (wives) to do, possess or enjoy a variety of resources concerning on information, education, capital, technology, and opportunities for business or work. While control concerns the extent to which men (husbands) and women (wives) have the power or ability in the decision-making process in planning, doing, possessing or enjoying of something (Nugraheni, 2012). 
Table 12. Access and Control of Resources.

\begin{tabular}{llrrrr}
\hline \multirow{2}{*}{ No } & \multicolumn{2}{c}{ Husband } & \multicolumn{2}{c}{ Wife } \\
\cline { 2 - 5 } & & Access $(\%)$ & Control $(\%)$ & Access $(\%)$ & Control (\%) \\
\hline 1 & Land & 100 & 99 & 100 & 61 \\
\hline 2 & Production tools & 100 & 96 & 93 & 30 \\
\hline 3 & Manpower & 98 & 79 & 28 & 53 \\
\hline 4 & Money & 98 & 76 & 100 & 74 \\
\hline 5 & Education & 100 & 98 & 98 & 24 \\
\hline 6 & Training & 100 & 100 & 100 & 22 \\
\hline 7 & Saving & 100 & 72 & 100 & 85 \\
\hline \multicolumn{2}{r}{ Average } & 68 & 61 & 61 & 34 \\
\hline \hline
\end{tabular}

Source: Processed of Primary Data, 2018.

Table 12 shows an average of 68 percent of access to resources in the household is performed by men (husbands) and women (wives) as much as 61 percent. In control of resources in the household, an average of 61 percent is performed by men (husbands) and 34 percent is done by women (wives). This result shows that access to and control over resources in households is greater for men (husbands).

Table 13. Access and Control over Benefits.

\begin{tabular}{llrrrr}
\hline \multirow{2}{*}{ No } & \multicolumn{2}{c}{ Husband } & \multicolumn{2}{c}{ Wife } \\
\cline { 3 - 6 } & & Access $(\%)$ & Control $(\%)$ & Access $(\%)$ & Control (\%) \\
\hline 1 & External income & 99 & 85 & 97 & 85 \\
\hline 2 & Ownership assets & 100 & 100 & 100 & 86 \\
\hline 3 & Basic needs & 100 & 53 & 100 & 53 \\
\hline 4 & Food and clothing & 100 & 25 & 100 & 82 \\
\hline 5 & Residence & 100 & 98 & 100 & 71 \\
\hline 6 & Education & 100 & 97 & 99 & 30 \\
\hline 7 & Political power & 99 & 78 & 36 & 50 \\
\hline & Average & 68 & 52 & 62 & 45 \\
\hline \hline
\end{tabular}

Source: Processed of Primary Data, 2018.

Table 13 shows an average of 68 percent of access to benefits in the household is performed by men (husbands) and women (wives) as much as 62 percent. The control of benefits in the household shows an average of 62 percent is performed by men (husbands) and as many as 45 percent is performed by women (wives). This result shows greater access and control over benefits in the household is performed by men (husband).

Greater access and control of resources and benefits in the household carried out by men (husbands) will lead to dominant decisions made more by men (husbands) in the household. If this happens to accept each other and do not blame it is not a problem in the household. Problems occur if this is carried out based on compulsion or demands to do which is part of custom, culture and other factors, which in each household member creates a sense of injustice. This will affect the potential of family-owned resources. 


\section{Factors Affecting the Gender Analysis Tool Activity Profile and Access and Control}

Discussion of issues related to gender must view at several factors related to the division of labor in the household in the profile of activities, access and control of the resources and benefits the household owned. Although these factors may not be easy to change, the analysis of these factors will provide a discussion of how much influence is taking place in the field. In addition, the assessment of the role factors in assessing impacts, opportunities, and constraints in realizing equal participation in the household can determine the right policy direction for the community being studied.

Table 14. Influencing Factors.

\begin{tabular}{llrr}
\hline No & \multicolumn{1}{c}{ Influencing factors } & Opportunity $(\%)$ & Constraints $(\%)$ \\
\hline 1 & Community norm and social hierarchy & 1 & 99 \\
\hline 2 & Demographic factors & 94 & 6 \\
\hline 3 & Structure of institutional / economic factors & 94 & 6 \\
\hline 4 & Political factor & 45 & 55 \\
\hline 5 & Legal parameter & 25 & 75 \\
\hline 6 & Training & 94 & 6 \\
\hline 7 & Community attitude toward external intervention & 92 & 8 \\
\hline \multicolumn{2}{r}{ Average } & 44 & 25 \\
\hline \hline
\end{tabular}

Source: Processed of Primary Data, 2018.

Table 14 shows the average number of factors influencing gender analysis one and two, namely: 44 percent are opportunities and 25 percent are constraints. Factors become opportunities or chances to increase utility in conducting household activities of rice farmers, based on the results of research, namely on demographic factors, institutional structure and economic conditions, training, and the community are quite accepting of external interventions. Factors become obstacles in carrying out rice farmer household activities, namely on community norms and social hierarchy, legal parameters, and political conditions. This is due to the strong norms, culture, customs, and customary laws of indigenous peoples influencing various activities carried out by rice farming households, thus becoming an obstacle for rice farming households.

\section{Implication}

Work time allocation the man (husband) is greater than the allocation of working time women at all stages of the productive sector and rice farming. This result gives a small effect on the allocation of working men (husbands) in the reproductive sector households. The results of this opinion (Norfahmi, Kusnadi, Nurmalina, \& Winandi, 2017) the intensity of the allocation of working men in the productive sector is greater in households because it has a great responsibility towards the fulfillment of the needs of household members. The allocation of work time male at productive sector gives effect to control over resources and benefits are greater in households. This led to the man (husband) is more dominant in many of the decisions made in the household. If it is mutual acceptance then it is not a problem in the household. Problem occurs if it is done based on forced or demands to do that is part of the indigenous, cultural and other factors that lead to a sense of injustice will be.

Work time allocation woman (wife) who is smaller at all stages of the productive sector and rice agriculture gave the magnitude of the effect on the allocation of time to work on the reproductive sector households and gives effect to control over resources and a smaller benefit in the household. The small 
allocation of working time women (wives) in the sector of compulsory work not caused productive woman (wife). According to Taridala et al. (2010) although the activities in the household does not generate cash income, women assume that housework is crucial. Involvement of women (wife) sector is a form of mutual productive petrified in family members. In contrast, the participation of the man (husband) in the reproductive sector.

The results of the regression analysis of the allocation of working time the man (husband) in the household which has a significant influence on relations and positiv on variable land area and the amount of rice production. The more expansive farmland of rice and rice production will increase the number of hours of work which you allocate the man (husband) in the rice farming. On the variables age, education level, number of family members, in addition to the rice farming income and there is no significant influence of relationship towards the allocation of working time the man (husband) in the rice farming. Among other causes, the average level of civic farmer who is still low and the use of technology in agriculture range from tilling until harvesting. While the amount of household income in addition to the agriculture does not have significant influence towards the allocation of working time the man (husband) on Agriculture rice, rice farming caused is principal livelihood and employment besides agriculture rice is done in spare time after finished doing farm work or while waiting for the rice crop has been planted rice ready for harvest.

The results of the regression analysis of the allocation of working time women (wives) in the household which has a significant influence on relations and positiv on variable land area. Extent of agricultural land of rice will be the number of hours women work (wife) helps the man (husband) working on the farm of rice. On a variable level of education and number of family members have a negative and significant influence. The rise in the level of education of women (wives) will reduce the amount of work allocation in agriculture and the increase of the number of family members will make the woman (wife) more work time allocating reproductive households and reduce the allocation of work on farming of rice. Variables age, the amount of rice production, and the amount of revenues in addition to the rice farm showed the result has no significant influence of relationship towards women's work time allocation (wife) on rice farming. One of the reasons is the woman (wife) is obliged to do the work of reproductive households, farm work is done after rice finished doing the work of reproductive households.

Factors that become obstacles in conducting household on average in the norms of society and social hierarchy, the parameters of the law, and political circumstances that existed in the Tanah Miring District of Merauke Regency. This is caused because the norms, culture, customs, and legal customs of indigenous communities is very strong affect the various activities performed. Factors that simply be an opportunity or a chance to increase the utility of doing various activities and activities of households in demographic factors, the structure of the institution and the State of the economy, training, community and receive enough against intervention from outside.

\section{CONCLUSION AND RECOMMEN- DATION}

The time allocation of men (husband) in rice farming is greater than the allocation of working time for women (wives). The amount of time allocation for men (husbands) in rice farming shows that men (husbands) are more responsible for fulfilling their needs in the household. The large allocation of working time for women (wives) on rice farming shows a significant role in helping men (husbands) 
in rice farming. The results of the study also show that the division of labor occurred between men (husbands) and women (wives) is not only men (husbands) as breadwinners in the household, but women (wives) are also involved in various productive activities of the household.

The allocation of male working time (husband) on rice farming is positively influenced by the variable of land area and amount of rice production, while the variables of age, level of education, number of family members, and income other than rice farming have no significant influence relationship.

The allocation of working time for women (wives) on rice farming is influenced positively by the variable of large area of rice farming, while negatively affected by education level variables and the number of family members. Age variables, the amount of rice production, and the amount of business income other than rice farming showed that the results did not have a significant influence relationship.

Gender analysis The Harvard model shows that on average productive work is carried out by men (husband) and on average reproductive work is carried out by women (wives). These results indicate the responsibility of men (husbands) as the head of the household in the family so that it is more dominant to allocate working time to productive work, while women (wives) as housewives allocate more working time to reproductive work.

Gender analysis The Harvard model shows that on average men (husbands) have greater access and control opportunities than women (wives). This causes men (husbands) to be more dominant in various decisions made in the household.

Gender analysis the Harvard Model for factors are sufficient to be an opportunity or chances to increase utility in carrying out various activities and activities of farmer households, namely demographic factors, institutional structure and economic conditions, training, and the community is quite accepting of interventions originate from outside. For factors become constraints in carrying out farmer household activities, namely on community norms and social hierarchy, legal parameters, and political conditions. This is due to the strong norms, culture, customs, and customary laws of indigenous peoples influence various activities carried out by rice farmer households.

Suggestions of this research are: 1) the magnitude allocation of working for women (wives) in helping men (husbands) in rice farming and the productive sector of households shows that women (wives) are large enough to contribute income to the family. The average shows the role of men (husbands) in the productive sector and women (wives) in the reproductive sector, it requires technical management of rice farming management and household productive sectors, management of the division of labor between men (husbands) and women (wife) in the household, and the importance of increasing the potential of the resources owned by the household. The expectation is to optimize the role of men (husbands) and women (wives) in the productive and reproductive sectors of households in improving the quality of household welfare; 2) Government policies are needed in various activities to support the development of rice agriculture such as mediators between farmers and local communities regarding customary rules and customary laws relating to land used by farmers. Approach and socialization of the program is needed to the local community regarding land release according to the ordinate specified, which will be used and formed into rice fields. This step serves as a form of appreciation and involvement of the community in the activity program. 


\section{REFERENCES}

Adenuga, A. H., Omotesho, O. A., Ojehomon, V. E. T., Diagne, A., Olorunsanya, E. O., \& Adenuga, O. M. (2013). Poverty Analysis of Rice Farming Households: A Multidimensional Approach. Albanian j. Agric. Sci., 12(4), 641-651.

Badan Pusat Statistik Kabupaten Merauke. (2016). Statistik Daerah Kabupaten Merauke. Merauke.

Dewan Ketahanan Pangan Papua, Badan Ketahanan Pangan dan Koordinasi Penyuluhan Papua, \& World Food Programe. (2015). Peta Ketahanan dan Kerentanan Pangan Papua Tahun 2015. Jayapura.

Ehrenberg, R. G., \& Smith, R. S. (2003). Modern Labor Economics: Theory and Public Policy. New York City: Pearson Education, Inc.

Ghozali, I. (2016). Aplikasi Analisis Multivariate dengan Program SPSS 21. Semarang: Badan Penerbit Universitas Diponegoro.

Gujarati, D. N., \& Porter, D. C. (2009). Dasar-dasar Ekonometrika. Jakarta: Penerbit Salemba Empat.

Istijanto. (2005). Riset Sumber Daya Manusia. Jakarta: PT Gramedia Pustaka Utama.

Kabasarang, D. C., Setiawan, A., \& Susanto, B. (2013). Uji Normalitas Menggunakan Statistik Jarque-Bera Berdasarkan Metode Bootstrap. Seminar Nasional Pendidikan Matematika.

Khuza'i, M. (2013). Problem Definisi Gender: Kajian atas Konsep Nature dan Nurture. Jurnal Studi Agama Dan Pemikiran Islam, 11(1), 101-118.
Lindawati. (2015). Analisis Faktor yang Mempengaruhi Perilaku Ekonomi dan Kesejahteraan Rumah Tangga Petani Usaha Tani Terpadu Padi-Sapi Di Provinsi Jawa Barat. Institut Pertanian Bogor.

Mangkuprawira, S. (1985). Alokasi Waktu dan Kontribusi Kerja Anggota Keluarga dalam Kegiatan Ekonomi Rumah Tangga. Institut Pertanian Bogor.

Nicholson, W. (1999). Teori Mikro Ekonomi Dasar dan Perluasan. Jakarta: Binarupa Aksara.

Nugraheni, S. W. (2012). Peran dan Potensi Wanita dalam Pemenuhan Kebutuhan Ekonomi Keluarga Nelayan. Journal of Educational Sosial Studies, 1(2), 104-111.

Puspitawati, H. (2012). Gender dan Keluarga : Konsep dan Realita di Indonesia. Bandung: IPB Press.

Reijntjes, C. (1999). Pertanian Masa Depan: Pengantar untuk Pertanian Berkelanjutan dengan Input Luar Rendah. Yogyakarta: Kanisius.

Rosada, I., \& Nurliani. (2016). A Review on Multi-Roles of Women and Their Influence on the Change of Functional Structure in the Farmer's Household. Agriculture and Agricultural Science, 9, 4753.

Saleh, E., \& Yunilas. (2004). Perbandingan Alokasi Waktu Tenaga Kerja Wanita dan Pria dalam Usaha Penggemukkan Sapi di Kecamatan Hamparan Perak Kabupaten Deli Serdang. Jurnal Komunikasi Penelitian, 16(6), 7076. 
Soetanto, J. A. D. (2008). Road to Kabupaten: Catatan Perjalanan di Pedalaman Papua. Jayapura: Penerbit Badan Pusat Statistik Provinsi Papua.

Taridala, S. A. A., Harianto, Siregar, H., \& Hardinsyah. (2010). Analisis Peran Gender dalam Pencapaian Ketahanan Pangan Rumah Tangga Petani di Kabupaten Konawe Selatan, Provinsi Sulawesi Tenggara. Forum Pascasarjana, 33(4), 263-274. 